\title{
Morphometric and Meristic Variations of Glossogobius Sparsipapillus along the Coastline in the Mekong Delta, Vietnam
}

\author{
Nguyen THD, Nguyen HTT, Canh TC, Nguyen YTN and Dinh QM* \\ Department of Biology, Can Tho University, Vietnam
}

*Corresponding author: Quang Minh Dinh, Department of Biology, School of Education, Can Tho University, 3/2 street, An Khanh ward, Ninh Kieu district, Can Tho 90000, Vietnam, Tel: 0909756705; Email: dmquang@ctu.edu.vn

\section{Research Article \\ Volume 3 Issue 1}

Received Date: February 12, 2020

Published Date: February 21, 2020

DOI: $10.23880 /$ izab- 16000211

\section{Abstract}

This study contributed to the variation of morphometric and meristic measurements of Glossogobius sparsipapillus, a target catching fish in the Mekong Delta. A total of 583 individuals (293 males and 290 females) were collected during dry and wet seasons (April 2019 to January 2020) at three studied sites from Vinh Hau, Hoa Binh, Bac Lieu to Dien Hai, Dong Hai, Bac Lieu and Tan Thuan, Dam Doi, Ca Mau. The analysis results showed that total length and body weight of this species varied with seasons and studied sites, but not genders. The variations of fish length and weight of males and females depended on seasons but not studied sites. The interaction of site and season variables influenced the change of fish length and weight. The results supplied additional knowledge for fish identification and ecological adaptation understanding in the study regions.

Keywords: Mekong Delta; Morphometry; Goby; Glossogobius Sparsipapillus

Abbrevations: TL: Total Length; W: Body Weight; HL: Head Length; BD: Body Depth; ED: Eye Diameter; DE: Distance of two Eyes; MD: Mouth Distance.

\section{Introduction}

Morphometric and meristic parameters play an important role in fish identification [1], which are used to classify fish from the marine to the freshwater area [2]. A few papers, however, provide data on morphometric and meristic parameters of gobiid species living along the coastline regions in the Mekong Delta. The goby Glossogobius sparsipapillus Akihito \& Meguro (1976) [3] is one of three species of the genus Glossogobius recorded in the Mekong Delta $[4,5]$ and lives mainly along the coastline from Bac Lieu to Ca Mau provinces [6]. This study aims to test if its morphometric and meristic parameters vary with different places along the coastline in the Mekong Delta. The variation of these parameters with gender and season variables are also provided in this study. The results will contribute to knowledge on morphometric and meristic parameters of this species, being used for understanding fish ecological adaption in the study region.

\section{Materials and Methods}

\section{Fish Collection and Analysis}

This study was carried out at three studied sites along coastline from Vinh Hau, Hoa Binh, Bac Lieu (VH,

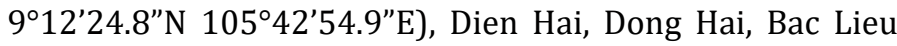
(DH, 9 $9^{\circ} 6^{\prime} 03.2^{\prime \prime} \mathrm{N} 105^{\circ} 29^{\prime} 49.1^{\prime \prime} \mathrm{E}$ ) and Tan Thuan, Dam Doi, Ca Mau (TT, 858'17.5”N 105²2'51.8”E, Figure 1). Gill nets were used to collect fish specimens monthly from April 2019 to January 2020. There are two main seasons including the dry season (January to May) and the wet season (June to December) in this study region. It rarely rains in the dry season but heavy rain in the wet season with $400 \mathrm{~mm}$ precipitation per month [6]. Fish specimens were identified based on the external morphology described by Akihito \& Meguro (1976) [3] and transported to the laboratory after collection.

-: sampling area; 1: Vinh Hau, Hoa Binh, Bac Lieu; 2: Dien Hai, 
Dong Hai, Bac Lieu; 3: Tan Thuan, Dam Doi, Ca Mau

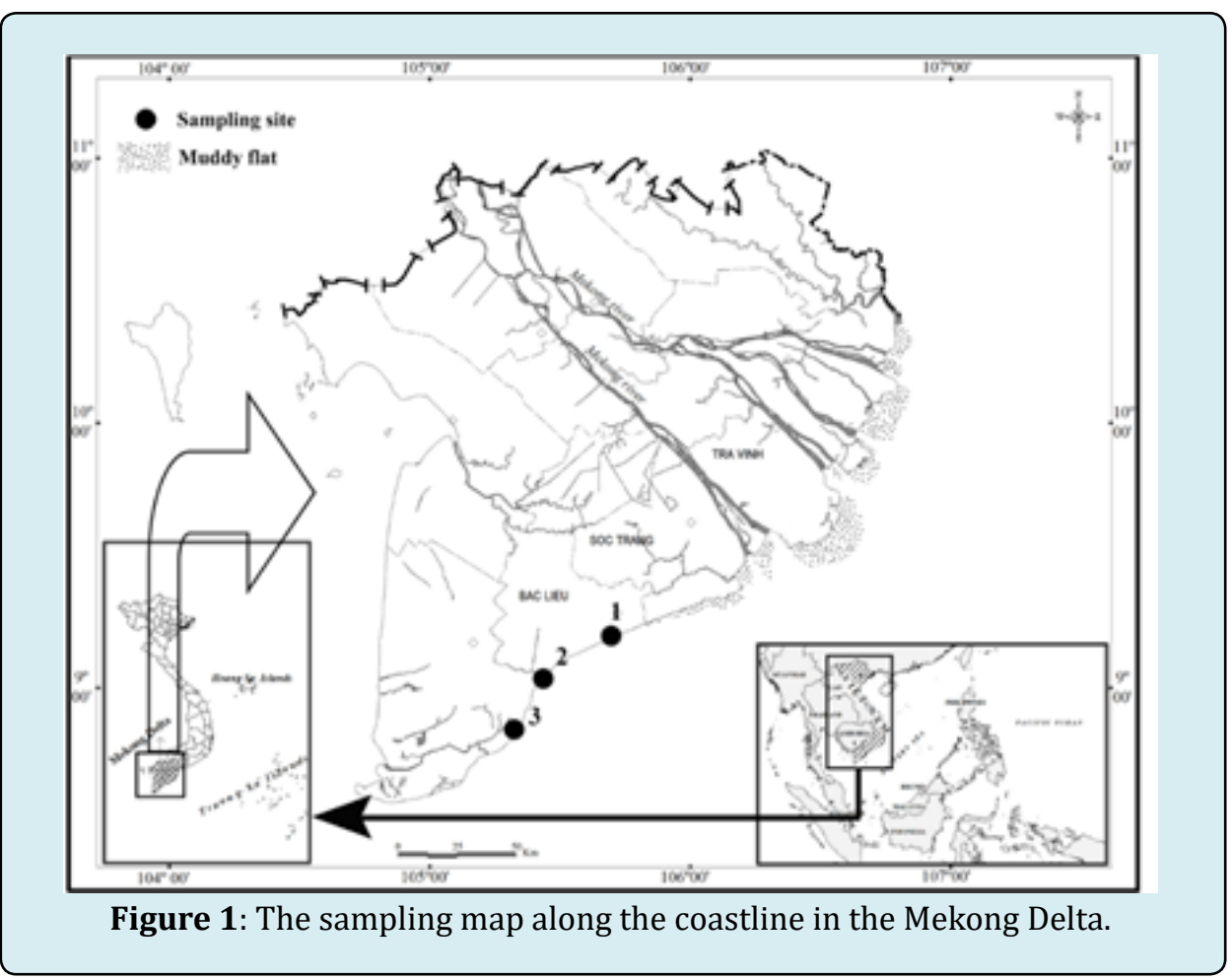

In the laboratory, after sex determination using genital papilla with triangle in males and oval in females. According to Daud, et al. [7], the morphometric and meristic parameters including the total length (TL), body weight (W), head length (HL), body depth (BD), eye diameter (ED), distance of two eyes (DE), mouth distance (MD), HL/TL, BD/TL, ED/HL, and DE/HL were measured.

\section{Data Analysis}

The changes of TL, W, HL, BD, ED, DE, MD, HL/TL, BD/TL, $\mathrm{ED} / \mathrm{HL}$ and DE/HL between genders and seasons were examined by t-test. One-way ANOVA was used to test the variation of these variables among three studied sites. The influence of the interaction of three variables including gender $\times$ season, gender $\times$ studied site, and season $\times$ studied site on the variation of TL, W, HL/TL, BD/TL, ED/HL, and DE/HL were examined by two-way ANOVA. The SPSS software v21 was used for data analysis. All tests were set at $P<0.05$.

\section{Results and Discussion}

\section{Study Site Description and Morphometric Variation}

The vegetation in $\mathrm{VH}$ and $\mathrm{DH}$ comprises mainly Avicennia alba and Rhizophora apiculata, whereas the vegetation TT was more diverse with many kinds of trees including Avicennia alba, Rhizophora apiculata, Lumnitzera racemosa,
Excoecaria agallocha, Rhizophora mucronata, Aegiceras floridum, and Nypa fruticans. The mean of temperature, $\mathrm{pH}$ and salinity were $28.6 \pm 0.8 \mathrm{SD}, 7.6 \pm 0.1 \mathrm{SD}$ and $23.8 \pm 1.3 \mathrm{SD}$ in $\mathrm{VH}, 29.7 \pm 1.0 \mathrm{SD}, 7.6 \pm 0.2 \mathrm{SD}$ and $23.8 \pm 2.6 \mathrm{SD}$ in $\mathrm{DH}$, and $30.0 \pm 0.6 \mathrm{SD}, 7.5 \pm 0.2 \mathrm{SD}$ and $23.8 \pm 2.9 \mathrm{SD}$ in TT, respectively. The seasonal change was found in salinity (t-test, $t_{\mathrm{vH}}=3.82$, $t_{\mathrm{DH}}=4.33$ and $t_{\mathrm{TT}}=4.13, P<0.01$ ), but not in temperature and $\mathrm{pH}(P>0.05$ for all cases).

Data analysis of 583 individuals (293 males and 290 females) showed that the average TL of this species varied significantly with the seasons $(t=9.71, P<0.05)$, but not by sex $(t=-4.26, P>0.05$, Table 1$)$. Specifically, the average TL of this species was $10.98 \pm 0.14$ SE in the dry season and $9.47 \pm 0.08$ SE in the wet season. Like TL, the average weight (W) of males and females was similar $(t=-2.88, P>0.05)$, while this value was different between dry and rainy seasons $(t=7.18$, $P<0.05)$. The difference in salinity between the dry and wet seasons and the vegetation between these three studied sites could result in the seasonal and spatial changes in TLs and Ws. It seems the dry season could be a favorable period for both males and female Glossogobius sparsipapillus in the studied sites. The seasonal change in $\mathrm{W}$ was found in Parapocryptes serperaster [8]. Meanwhile, the TL and $\mathrm{W}$ of some gobiid species living in the Mekong Delta, e.g., Parapocryptes serperaster [8], Periophthalmodon schlosseri [9], Trypauchen vagina [10], Boleophthalmus boddarti [11], 
Stigmatogobius pleurostigma [12] and Periophthalmodon septemradiatus [13] do not vary between dry season and wet season (Table 1).

\begin{tabular}{|c|c|c|c|}
\hline Morphometry & Category & Number of fish & Mean \pm SE \\
\hline \multirow{2}{*}{ Fish total length } & Male & 293 & $10.30 \pm 0.11^{\mathrm{a}}$ \\
\hline & Female & 290 & $9.64 \pm 0.10^{\mathrm{a}}$ \\
\hline \multirow{2}{*}{ Fish body weight } & Male & 293 & $9.65 \pm 0.32^{\mathrm{a}}$ \\
\hline & Female & 290 & $8.36 \pm 0.30^{\mathrm{a}}$ \\
\hline \multirow{2}{*}{ Fish total length } & Dry & 193 & $10.98 \pm 0.14^{\mathrm{a}}$ \\
\hline & Wet & 390 & $9.47 \pm 0.08^{\mathrm{b}}$ \\
\hline \multirow{2}{*}{ Fish body weight } & Dry & 193 & $11.21 \pm 0.43^{\mathrm{a}}$ \\
\hline & Wet & 390 & $7.92 \pm 0.24^{b}$ \\
\hline
\end{tabular}

Note: Different letters in each category represented the significant difference.

Table 1: The variation in fish length and weight of Glossogobius sparsipapillus between genders and seasons.

The average TL of this species varies with the study site, the highest value was in $\mathrm{DH}(10.31 \pm 0.15 \mathrm{SE} \mathrm{cm})$, the lowest one was in TT $(9.57 \pm 0.10 \mathrm{SE} \mathrm{cm})$ (one-way ANVOA, $\mathrm{F}=9.94, P<0.01$, Figure 2). This change was also shown in Ws, the highest values were in DH $(10.12 \pm 0.45)$, the lowest one was in TT ( $7.99 \pm 0.31$, ANVOA, $F=8.53, P<0.01$, Figure 3 ).
This change may be due to differences in the environmental conditions of the study sites. The change of TLs and Ws by location was also found in Periophthalmodon septemradiatus as its TLs and Ws reached the highest values in BD $(9.2 \pm 0.1$ SE $\mathrm{cm} \mathrm{TL}$ and $7.23 \pm 0.21 \mathrm{~g} \mathrm{~W}$ ) and the lowest point in ALT (7.6 \pm 0.1 SE cm TL $4.17 \pm 0.12 \mathrm{~g}$ ) [13].

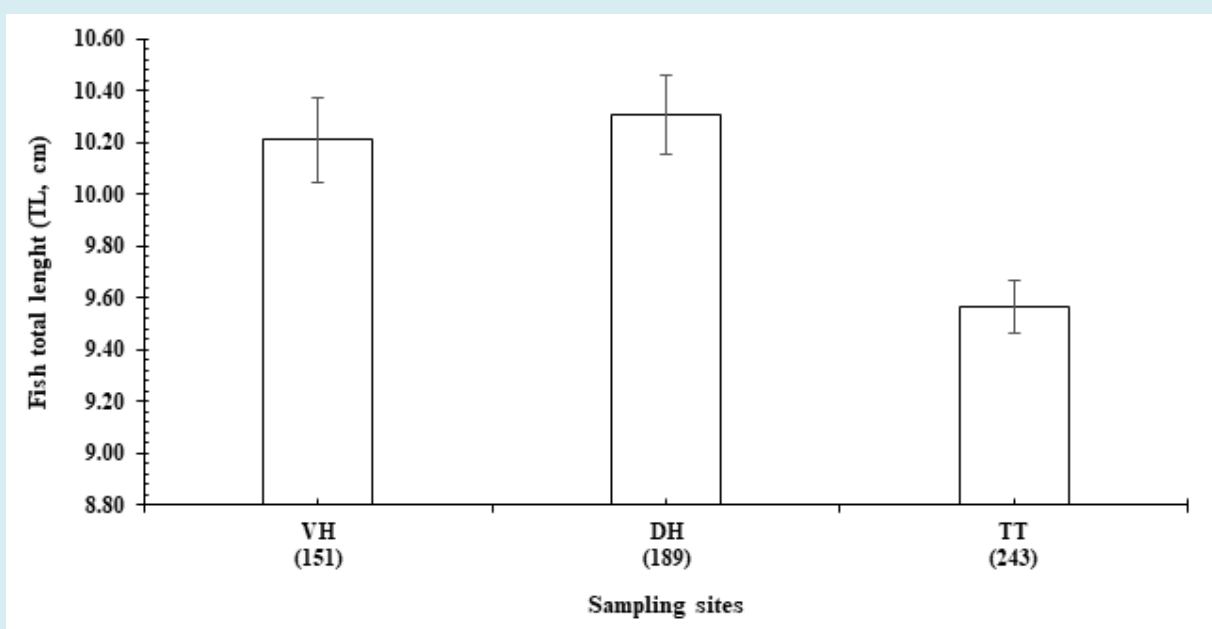

(VH: Vinh Hau, Hoa Binh, Bac Lieu; DH: Dien Hai, Dong Hai, Bac Lieu; TT: Tan Thuan, Dam Doi, Ca Mau; number in parentheses: number of fish in each site; vertical bar was standard error of mean; different letters represented the significant difference) Figure 2: The variation in fish total length at three studied sites.

The seasonal change of TLs of this goby depended on gender (two-way ANOVA, $F=8.63, P<0.01$, Figure 4) and studied site (ANOVA, $F=7.28, P<0.01$, Figure 5 ), which was also found in Periophthalmodon septemradiatus [13]. However, TLs of this goby was not regulated by the interaction of gender and studied site (ANOVA, $F=2.04, \mathrm{P}>0.05$, Figure 6), whereas the reverse case was true for TLs of Periophthalmodon septemradiatus [13]. Like Periophthalmodon septemradiatus [13], Ws in the dry and wet seasons varied according to gender (ANOVA, $F=7.82, P<0.01$, Figure 7 ) and studied site (ANOVA, $F=8.00, P<0.01$, Figure 8 ) variables. The interaction of gender and studied sites did not influence the change of Ws of this goby (ANOVA, $F=0.82, P<0.05$, Figure 9 ). 


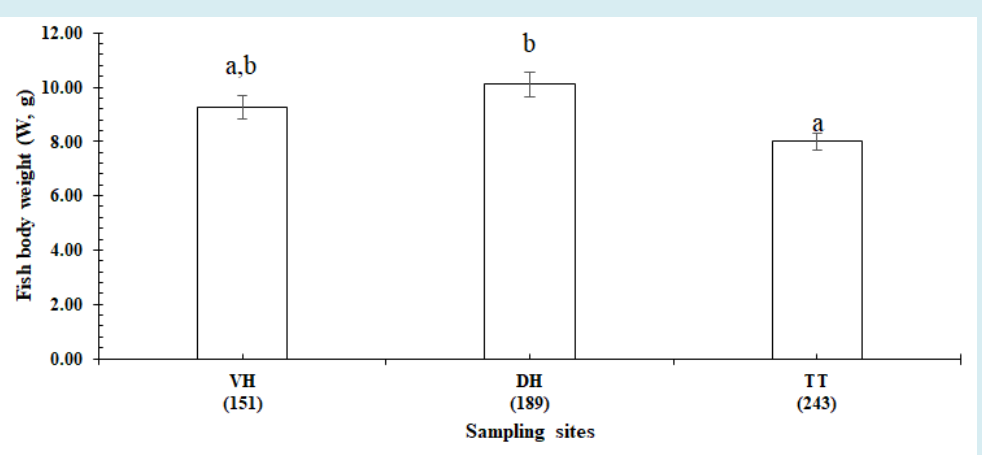

(VH: Vinh Hau, Hoa Binh, Bac Lieu; DH: Dien Hai, Dong Hai, Bac Lieu; TT: Tan Thuan, Dam Doi, Ca Mau; number in parentheses: number of fish in each site; vertical bar: standard error of mean; different letters represented the significant difference)

Figure 3: The variation in body weight at three studied sites.

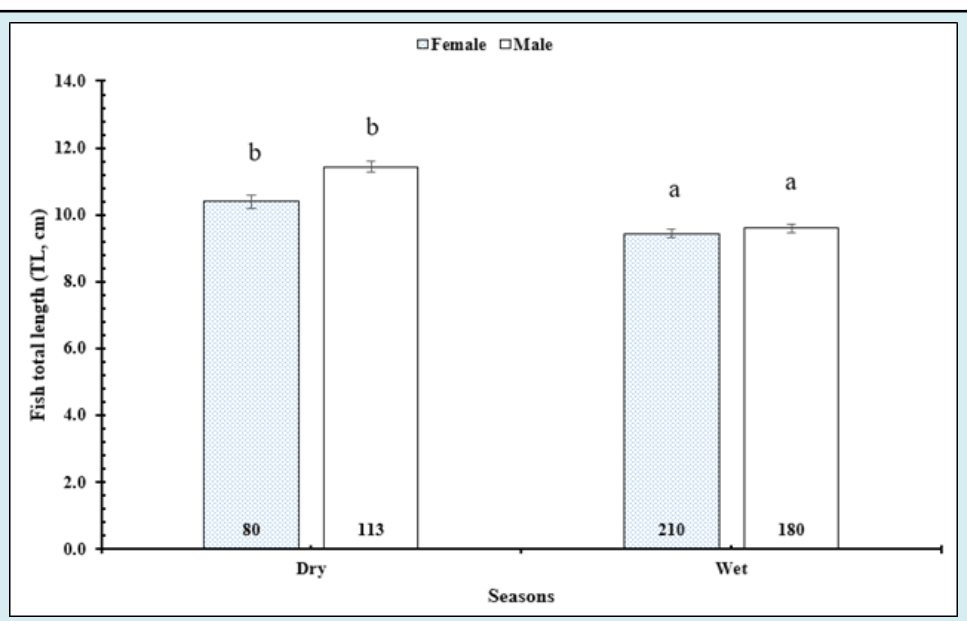

(Number in each column: number of fish in each season; vertical bar: standard error of mean; different letters represented the significant differences)

Figure 4: The interaction of gender and season on the change of fish total length.

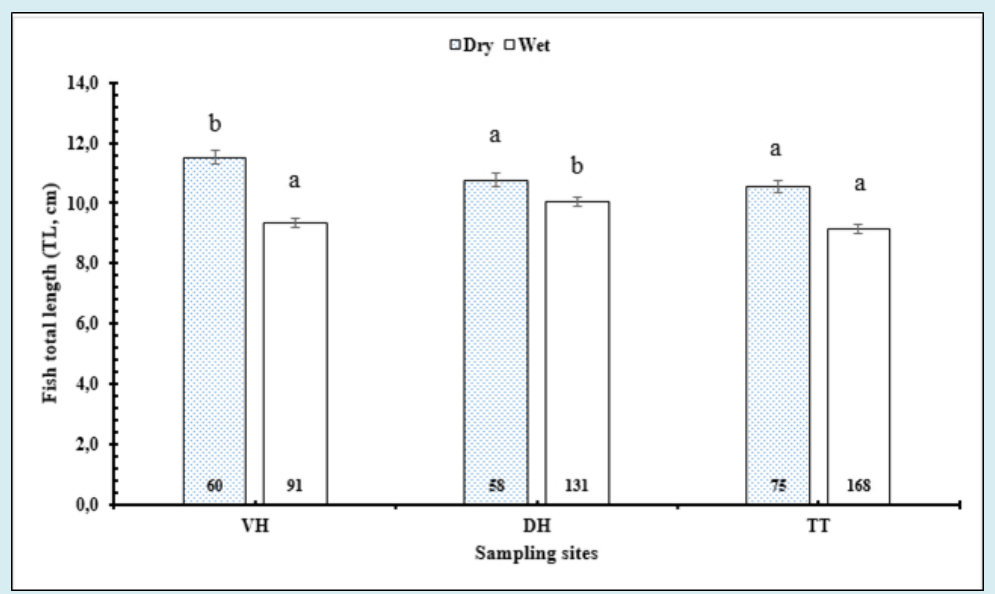

(VH: Vinh Hau, Hoa Binh, Bac Lieu; DH: Dien Hai, Dong Hai, Bac Lieu; TT: Tan Thuan, Dam Doi, Ca Mau; number in each column: number of fish in each site; the vertical bar: standard error of mean; different letters represented the significant difference)

Figure 5: The interaction of season and site on the change of fish total length. 


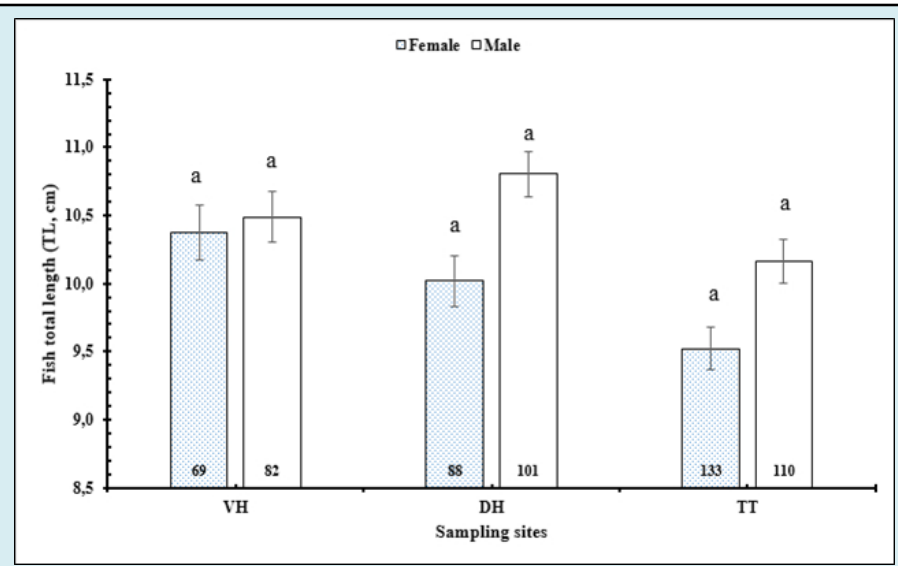

(VH: Vinh Hau, Hoa Binh, Bac Lieu; DH: Dien Hai, Dong Hai, Bac Lieu; TT: Tan Thuan, Dam Doi, Ca Mau; number in each column: number of fish in each site; the vertical bar: standard error of mean)

Figure 6: The interaction of gender and site on the change of fish total length.

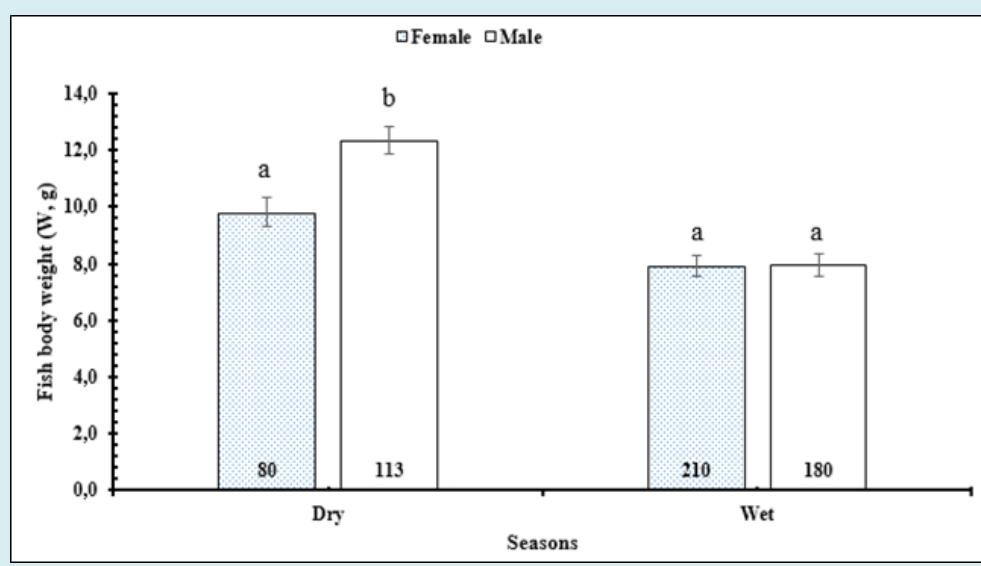

(Number in each column: number of fish in each season; the vertical bar: standard error of mean; different letters represented the significant differences)

Figure 7: The interaction of gender and season on the change of fish total length.

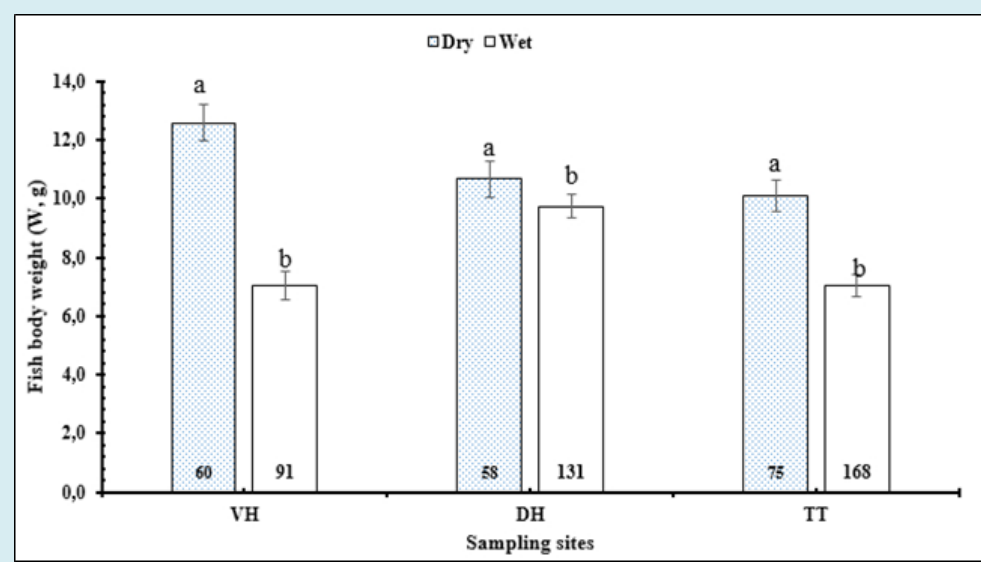

(VH: Vinh Hau, Hoa Binh, Bac Lieu; DH: Dien Hai, Dong Hai, Bac Lieu; TT: Tan Thuan, Dam Doi, Ca Mau; the number in each column: number of fish in each site; the vertical bar: standard error of mean; different letters represented the significant differences)

Figure 8: The interaction of season and site on the change of fish body weight. 


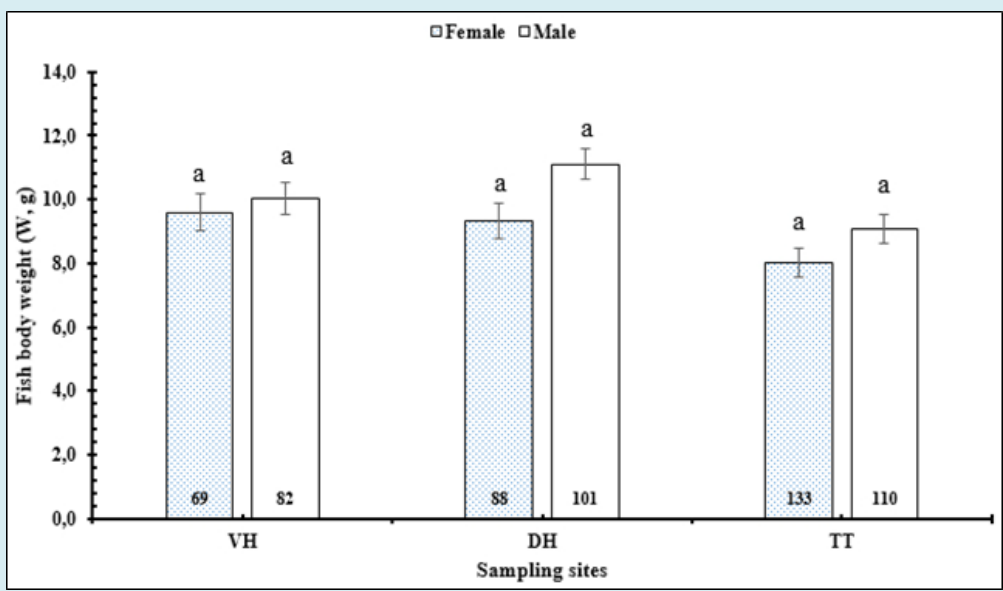

(VH: Vinh Hau, Hoa Binh, Bac Lieu; DH: Dien Hai, Dong Hai, Bac Lieu; TT: Tan Thuan, Dam Doi, Ca Mau; number in each column: number of fish in each site; the vertical bar: standard error of mean)

Figure 9: The interaction of gender and sites on the change of fish body weight.

\section{Meristic Variation}

The meristic parameters of male Glossogobius sparsipapillus were similar to those of females, except for BD and ED/HL, which was presented in Table 2.

\begin{tabular}{|c|c|c|c|c|c|c|}
\hline Morphometric parameter & Site & Number of fish & Mean & Standard deviation & $t$ & $\boldsymbol{P}$ \\
\hline \multirow{2}{*}{ ED } & Female & 290 & 0.37 & 0.07 & \multirow{2}{*}{0.27} & \multirow{2}{*}{0.1} \\
\hline & Male & 293 & 0.38 & 0.07 & & \\
\hline \multirow{2}{*}{$\mathrm{DE}$} & Female & 290 & 0.23 & 0.09 & \multirow{2}{*}{14.1} & \multirow{2}{*}{0} \\
\hline & Male & 293 & 0.26 & 0.1 & & \\
\hline \multirow{2}{*}{$\mathrm{BD}$} & Female & 290 & 1.18 & 0.3 & \multirow{2}{*}{0.01} & \multirow{2}{*}{0.93} \\
\hline & Male & 293 & 1.23 & 0.29 & & \\
\hline \multirow{2}{*}{ HL } & Female & 290 & 2.28 & 0.47 & \multirow{2}{*}{0.78} & \multirow{2}{*}{0.37} \\
\hline & Male & 293 & 2.37 & 0.48 & & \\
\hline \multirow{2}{*}{ MD } & Female & 290 & 0.96 & 0.23 & \multirow{2}{*}{0.45} & \multirow{2}{*}{0.5} \\
\hline & Male & 293 & 1.04 & 0.24 & & \\
\hline \multirow{2}{*}{$\mathrm{HL} / \mathrm{TL}$} & Female & 290 & 24.07 & 1.45 & \multirow{2}{*}{2.37} & \multirow{2}{*}{0.12} \\
\hline & Male & 293 & 23.54 & 1.82 & & \\
\hline \multirow{2}{*}{$\mathrm{BD} / \mathrm{TL}$} & Female & 290 & 12.31 & 1.65 & \multirow{2}{*}{1.36} & \multirow{2}{*}{0.24} \\
\hline & Male & 293 & 12.01 & 1.63 & & \\
\hline \multirow{2}{*}{$\mathrm{ED} / \mathrm{HL}$} & Female & 290 & 17.86 & 4.8 & \multirow{2}{*}{13.28} & \multirow{2}{*}{0} \\
\hline & Male & 293 & 20.01 & 5.89 & & \\
\hline \multirow{2}{*}{ DE/HL } & Female & 290 & 30.62 & 5.86 & \multirow{2}{*}{0.58} & \multirow{2}{*}{0.44} \\
\hline & Male & 293 & 30.63 & 6.03 & & \\
\hline
\end{tabular}

Table 2: The variation in meristic parameters of Glossogobius sparsipapillus between genders.

The difference in the salinity between the dry and wet seasons could lead to the seasonal change of some meristic parameters of Glossogobius sparsipapillus such as DE, BD, HL,
HL/TL. BD/TL, ED/HL, and DE/HL, which was presented in Table 3. 


\begin{tabular}{|c|c|c|c|c|c|c|}
\hline Morphometric parameter & Site & Number of fish & Mean & Standard deviation & $t$ & $P$ \\
\hline \multirow{2}{*}{ ED } & Dry & 193 & 0.39 & 0.07 & \multirow{2}{*}{3.06} & \multirow{2}{*}{0.8} \\
\hline & Wet & 390 & 0.36 & 0.06 & & \\
\hline \multirow{2}{*}{$\mathrm{DE}$} & Dry & 193 & 0.29 & 0.12 & \multirow{2}{*}{125.35} & \multirow{2}{*}{0} \\
\hline & Wet & 390 & 0.23 & 0.07 & & \\
\hline \multirow{2}{*}{$\mathrm{BD}$} & Dry & 193 & 1.3 & 0.26 & \multirow{2}{*}{7.68} & \multirow{2}{*}{0.01} \\
\hline & Wet & 390 & 1.15 & 0.3 & & \\
\hline \multirow{2}{*}{ HL } & Dry & 193 & 2.56 & 0.5 & \multirow{2}{*}{12.47} & \multirow{2}{*}{0} \\
\hline & Wet & 390 & 2.2 & 0.42 & & \\
\hline \multirow{2}{*}{ MD } & Dry & 193 & 1.09 & 0.22 & \multirow{2}{*}{1.22} & \multirow{2}{*}{0.27} \\
\hline & Wet & 390 & 0.95 & 0.24 & & \\
\hline \multirow{2}{*}{$\mathrm{HL} / \mathrm{TL}$} & Dry & 193 & 24.04 & 1.54 & \multirow{2}{*}{4.36} & \multirow{2}{*}{0.03} \\
\hline & Wet & 390 & 23.69 & 1.71 & & \\
\hline \multirow{2}{*}{$\mathrm{BD} / \mathrm{TL}$} & Dry & 193 & 12.17 & 1.57 & \multirow{2}{*}{11.24} & \multirow{2}{*}{0} \\
\hline & Wet & 390 & 12.16 & 1.69 & & \\
\hline \multirow{2}{*}{$\mathrm{ED} / \mathrm{HL}$} & Dry & 193 & 19.92 & 6.7 & \multirow{2}{*}{44.84} & \multirow{2}{*}{0} \\
\hline & Wet & 390 & 18.41 & 4.64 & & \\
\hline \multirow{2}{*}{$\mathrm{DE} / \mathrm{HL}$} & Dry & 193 & 29.32 & 4.42 & \multirow{2}{*}{43.15} & \multirow{2}{*}{0} \\
\hline & Wet & 390 & 31.31 & 6.49 & & \\
\hline
\end{tabular}

Table 3: The variation in meristic parameters of Glossogobius sparsipapillus between seasons.

Similarly, most of the meristic parameters including ED, DE, HL, HL/TL, ED/HL and DE/HL of Glossogobius sparsipapillus varied study sites (one-way ANOVA, $P<0.05$ for all cases) and recorded in Table 4. This could result from the difference in vegetation among three studied sites.

\begin{tabular}{|c|c|c|c|c|c|c|c|c|}
\hline $\begin{array}{c}\text { Morphometric } \\
\text { parameter }\end{array}$ & Site & $\begin{array}{c}\text { Number of } \\
\text { fish }\end{array}$ & Mean & $\begin{array}{l}\text { Standard } \\
\text { deviation }\end{array}$ & Minimum & Maximum & $F$ & $P$ \\
\hline \multirow{3}{*}{ ED } & $\mathrm{VH}$ & 151 & 0.39 & 0.07 & 0.2 & 0.5 & \multirow{3}{*}{13.89} & \multirow{3}{*}{0} \\
\hline & $\mathrm{DH}$ & 189 & 0.39 & 0.08 & 0.3 & 0.6 & & \\
\hline & TT & 243 & 0.36 & 0.06 & 0.2 & 0.5 & & \\
\hline \multirow{3}{*}{$\mathrm{DE}$} & $\mathrm{VH}$ & 151 & 0.31 & 0.13 & 0.1 & 0.7 & \multirow{3}{*}{27.54} & \multirow{3}{*}{0} \\
\hline & $\mathrm{DH}$ & 189 & 0.26 & 0.1 & 0.1 & 0.6 & & \\
\hline & $\mathrm{TT}$ & 243 & 0.23 & 0.07 & 0.1 & 0.5 & & \\
\hline \multirow{3}{*}{$\mathrm{BD}$} & $\mathrm{VH}$ & 151 & 1.21 & 0.28 & 0.5 & 1.8 & \multirow{3}{*}{5.38} & \multirow{3}{*}{0.05} \\
\hline & DH & 189 & 1.3 & 0.35 & 0.8 & 2.2 & & \\
\hline & $\mathrm{TT}$ & 243 & 1.22 & 0.24 & 0.8 & 2.2 & & \\
\hline \multirow{3}{*}{ HL } & $\mathrm{VH}$ & 151 & 2.45 & 0.53 & 1.5 & 3.8 & \multirow{3}{*}{11.79} & \multirow{3}{*}{0} \\
\hline & $\mathrm{DH}$ & 189 & 2.5 & 0.55 & 0.7 & 4 & & \\
\hline & $\mathrm{TT}$ & 243 & 2.29 & 0.36 & 1.7 & 3.6 & & \\
\hline \multirow{3}{*}{ MD } & $\mathrm{VH}$ & 151 & 1.05 & 0.17 & 0.65 & 1.55 & \multirow{3}{*}{0.81} & \multirow{3}{*}{0.44} \\
\hline & DH & 189 & 1.03 & 0.25 & 0.55 & 1.7 & & \\
\hline & TT & 243 & 1.03 & 0.2 & 0.6 & 1.8 & & \\
\hline
\end{tabular}




\begin{tabular}{|c|c|c|c|c|c|c|c|c|}
\hline \multirow{3}{*}{ HL/TL } & $\mathrm{VH}$ & 151 & 11.62 & 1.24 & 7.58 & 14.29 & \multirow{3}{*}{20.2} & \multirow{3}{*}{0} \\
\hline & DH & 189 & 12.37 & 1.63 & 9.09 & 19.59 & & \\
\hline & $\mathrm{TT}$ & 243 & 12.52 & 1.32 & 9.18 & 16.32 & & \\
\hline \multirow{3}{*}{$\mathrm{BD} / \mathrm{TL}$} & $\mathrm{VH}$ & 151 & 23.78 & 1.7 & 16.02 & 27.78 & \multirow{3}{*}{1.38} & \multirow{3}{*}{0.25} \\
\hline & $\mathrm{DH}$ & 189 & 24.01 & 1.72 & 9.33 & 29.9 & & \\
\hline & $\mathrm{TT}$ & 243 & 23.77 & 1.35 & 18.97 & 28.08 & & \\
\hline \multirow{3}{*}{ ED/HL } & $\mathrm{VH}$ & 151 & 31.88 & 5.21 & 21.43 & 50 & \multirow{3}{*}{14.81} & \multirow{3}{*}{0} \\
\hline & DH & 189 & 29.61 & 5.02 & 20 & 43.75 & & \\
\hline & TT & 243 & 29.15 & 4.84 & 18.18 & 44.44 & & \\
\hline \multirow{3}{*}{ DE/HL } & $\mathrm{VH}$ & 151 & 22.95 & 6.98 & 12.5 & 40.74 & \multirow{3}{*}{45.33} & \multirow{3}{*}{0} \\
\hline & $\mathrm{DH}$ & 189 & 18.78 & 4.8 & 10 & 36.84 & & \\
\hline & TT & 243 & 17.9 & 4.31 & 8 & 31.03 & & \\
\hline
\end{tabular}

Note: VH: Vinh Hau, Hoa Binh, Bac Lieu; DH: Dien Hai, Dong Hai, Bac Lieu; TT: Tan Thuan, Dam Doi, Ca Mau.

Table 4: The variation in meristic parameters of Glossogobius sparsipapillus between studied sites.

The variation of $\mathrm{HL} / \mathrm{TL}, \mathrm{BD} / \mathrm{TL}$ and $\mathrm{DE} / \mathrm{HL}$ of Glossogobius sparsipapillus depended on the interaction of gender $\times$ season (two-way ANOVA, $F_{\mathrm{HL} / \mathrm{TL}}=6.60, F_{\mathrm{BD} / \mathrm{HL}}=5.64$, $\left.F_{\mathrm{DE} / \mathrm{HL}}=2.47, P<0.05\right)$ and season $\times$ studied site $\left(F_{\mathrm{HL} / \mathrm{TL}}=3.18\right.$, $\left.F_{\mathrm{BD} / \mathrm{TL}}=3.54, F_{\mathrm{DE} / \mathrm{HL}}=9.95, P<0.05\right)$, but not gender $\times$ studied site $\left(F_{\mathrm{HL} / \mathrm{TL}}=0.26, F_{\mathrm{BD} / \mathrm{HL}}=1.81, F_{\mathrm{DE} / \mathrm{HL}}=0.36, P>0.05\right)$. The variation of ED/HL of species depended on the interaction of season $\times$ studied site $(F=16.83, P<0.05)$ did not gender $\times$ season $(F=0.51, P>0.05)$ and gender $\times$ studied site $(F=0.85, P>0.05)$. Differences in the morphology of Glossogobius sparsipapillus in different coastal locations from VH to DH and TT could result in wide distribution and morphological flexibility of this goby species in the Mekong Delta. The spatial change in meristic variables was also found in Periophthalmodon septemradiatus [13].

In conclusion, this goby displayed spatiotemporal changed in morphometric and meristic variables, seeming species adapted well to the study areas. There was a need to continue to work on Glossogobius sparsipapillus's COI and Cytb genes to confirm if this goby showed a genetic variation among along the coastline in the Mekong Delta.

\section{Acknowledgment}

This research is funded by Can Tho University under grant number TSV2019-111. We are grateful to local people in the studied site for fish collection.

\section{References}

1. Strauss RE, Bond CE (1990) Taxonomic Methods: Morphology. In: Schreck CB, Moyle PB, et al. (Eds.), Methods for fish biology, American Fisheries Society, Maryland, pp: 109-140.
2. Nelson J, Grande T, Wilson M (2016) Fishes of the world. John Wiley \& Sons, New York, United States, pp: 6-707.

3. Akihito P, Meguro K (1976) Glossogobius sparsipapillus, a new species of goby from Viet Nam, Japanese Journal of Ichthyology 23: 9-11.

4. Nguyen VH (2005) Freshwater fish of Viet Nam, Agriculture Publishing House.

5. Tran DD, Shibukawa K, Nguyen TP, Ha PH, Tran XL, et al. (2013) Fishes of Mekong Delta, Vietnam, Can Tho University Publisher, Can Tho University, Vietnam.

6. Le T, Nguyen MT, Nguyen VP, Nguyen DC, Pham XH, et al. (2006) Provinces and City in the Mekong Delta, Education Publishing House, VI, Ha Noi (in Vietnamese).

7. Daud SK, Mohammadi M, Siraj SS, Zakaria MP (2005) Morphometric analysis of Malaysian oxudercine goby, Boleophthalmus boddarti (Pallas, 1770). Pertanika Journal of Tropical Agricultural Science 28: 121-134.

8. Dinh QM, Qin JG, Dittmann S, Tran DD (2016) Morphometric variation of Parapocryptes serperaster (Gobiidae) in dry and wet seasons in the Mekong Delta, Vietnam. Ichthyological Research 63: 267-274.

9. Dinh QM (2016) Growth and body condition variation of the giant mudskipper Periophthalmodon schlosseri in dry and wet seasons. Tạp chi Sinh học 38: 352-358.

10. Dinh QM (2016) Growth pattern and body condition of Trypauchen vagina in the Mekong Delta, Vietnam, The Journal of Animal and Plant Sciences 26: 523-531.

11. Dinh QM (2017) Morphometric, growth and condition 
factor variations of Boleophthalmus boddarti in the Mekong delta, Vietnam, Iranian Journal of Fisheries Sciences 16(2): 822-831.

12. Dinh QM (2017) Morphometrics and condition factor dynamics of the goby Stigmatogobius pleurostigma (Bleeker 1849) during dry and wet seasons in the
Mekong Delta, Vietnam, Asian Fisheries Sciences 30: 1725.

13. Dinh MQ, Tran TL, Nguyen TYN (2018) The flexibility of morphometric and meristic measurements of Periophthalmodon septemradiatus (Hamilton, 1822) in Hau river, Journal of Science and Technology 187: 81-89. 